\title{
ŹRÓDŁA ELEKTRONICZNE W PRACY TEOLOGA SYSTEMATYKA
}

\begin{abstract}
Streszczenie
Postęp techniczny związany z upowszechnieniem elektronicznej formy publikacji oraz z rozwojem Internetu, kształtującym nowy status komunikacji, w rewolucyjny sposób wpłynął na sposób uprawiania nauki. Zmiana dotknęła także metod prowadzenia badań i rozpowszechniania ich wyników w teologii. Teologia systematyczna (traktowana tu jako obszar badań z teologii fundamentalnej, dogmatycznej i moralnej) jest specjalizacją teologiczną, która odwołuje się do wielu typów właściwych dla siebie źródeł (Biblia, nauka Kościoła, historia teologii, wiara ludu Bożego, liturgia itd.), a także rezultatów badań w innych naukach, a w końcu także wymaga uczestnictwa w toczącym się aktualnie dyskursie teologicznym. Stąd wspomniane zmiany ułatwiające dostęp do materiałów źródłowych i aktualnych publikacji mają wielkie znaczenie dla teologa, pod warunkiem zdobycia umiejętności posługiwania się nowymi technologiami. Ze względu na wielką liczbę źródeł udostępnionych w Internecie można w krótkim opracowaniu jedynie - nie zbliżając się do kompletności prezentacji - wskazać przez pogrupowanie różne sposoby ich publikacji. W ten sposób możliwa jest ich przybliżona charakterystyka i wstępna ocena wiarygodności. Dokonany przegląd pokazuje, że wiarygodność publikacji zasadniczo jest dziedziczona od podmiotów publikujących je: stąd pierwszeństwo mają instytucje naukowe, uznane wydawnictwa, nowe podmioty ukonstytuowane $\mathrm{w}$ przestrzeni Internetu, o ile przedstawiają jasną politykę naukową. Równocześnie, wobec ciągle wzrastającej ilości informacji, ważna dla naukowca jest orientacja w świecie baz danych, szczególnie tych dziedzinowych, zarówno bibliograficznych, jak i pełnotekstowych. Należy zauważyć, że niebagatelną formą rozwoju myśli teologicznej, niewykorzystaną
\end{abstract}

* Ks. Jacek Kempa - dr hab. teologii; Wydział Teologiczny, Uniwersytet Śląski w Katowicach; e-mail: jacek.kempa@us.edu.pl

https://orcid.org/0000-0002-1965-785X 
jeszcze w wysokim stopniu przez środowisko teologiczne, jest umożliwiona w Internecie wymiana między naukowcami: bezpośrednia bądź odbywająca się za pośrednictwem wyspecjalizowanych platform.

Słowa kluczowe: źródła elektroniczne; teologia w Internecie; teologia systematyczna; komunikacja naukowa; Open Access; Nauka 2.0

Opracowanie prezentuje zagadnienie zastosowania elektronicznych źródeł informacji naukowej oraz elektronicznych dokumentów źródłowych w praktyce badań teologicznych w zakresie teologii systematycznej. Tytułowe wyrażenie „źródła elektroniczne" będzie w tym artykule odnosić się do obu wymienionych sfer. Właściwą prezentację poprzedzi krótkie przedstawienie toku pracy, właściwego dla tego zakresu teologii i wynikającego $\mathrm{z}$ niego zapotrzebowania na literaturę źródłową. Logika omówienia dokonanego w głównej części nawiązuje do ciągu prac teologa, który zakłada najpierw lekturę źródeł, następnie przestudiowanie stanu badań i dyskusji na dany temat, konsultacje, a następnie redakcję tekstu.

Taki tryb postępowania różni się od prezentacji, jakiej zwykle dokonuje specjalista z zakresu informacji naukowej, starający się o kompletny i zrównoważony obraz wybranego zakresu narzędzi elektronicznych i o poprawne metodologicznie badania nad ich praktycznym stosowaniem przez określone grupy użytkowników. W przypadku zaproponowanego tematu chodzi o próbę zarysowania całości obszaru poszukiwań w przestrzeni elektronicznej, typowych dla aktywności naukowej ważnej dla teologa. Stąd też dwa odrębne poziomy - informacji o źródłach i dostępności samych źródeł - zostaną w niniejszym omówieniu odróżnione, ale nie będą ściśle od siebie oddzielone. Praca powstaje jako rezultat doświadczeń akademickiego teologa, dlatego postulat kompletności prezentacji tak szerokiego pola zagadnień ustępuje miejsca staraniom o rzetelność sprawozdania z praktyki pracy. Ponadto mimo starania o nawiązanie do zwykłych celów naukowej bezstronności prezentacji nieunikniona będzie ocena wynikająca z jednostkowej, własnej analizy potrzeb, a przede wszystkim z własnej praktyki, a więc naznaczona partykularnym doświadczeniem, wzmagającym selektywność materiału i subiektywność stawianych tez. Pozostaje wyrazić nadzieję, że tę słabość niniejszej prezentacji zrównoważyć może - znajdująca się niejako po przeciwnej stronie wartość głosu z praktyki użytkownika „nowej biblioteki”, akademickiego teologa.

\section{Potrzeby. Warsztat teologa systematyka}

Spróbujmy zarysować zakres potencjalnych obszarów źródeł wiedzy, do których uwzględnienia zobowiązany jest lub może być teolog systematyk. Teologia systematyczna ${ }^{1}$ czerpie z szerokiego zakresu źródeł. Oczywiście, nie zawsze cho-

${ }^{1} \mathrm{~W}$ ujęciu zakresu teologii systematycznej idę tutaj za ostatnią koncepcją przedstawioną w artykule: H. Hoping, Systematische Theologie, w: Lexikon für Theologie und Kirche, t. 9, Freiburg, Basel, Wien 1993-2001, kol.1220-1221. Zgodnie z nią do teologii systematycznej zaliczają się: teologia fundamentalna, dogmatyczna i moralna. Inna koncepcja każe wyłączyć z tego zbiorowego pojęcia nie tylko teologię moralną, lecz także teologię fundamentalną, pozostawiając ostatecznie teologię dogmatyczną. (Por. E. Wójcik, Systematyczna teologia, w: Encyklopedia Katolicka, t. 18, red. E. Gigilewicz, Lublin 2013, kol.1380.). Takie węższe rozumienie teologii systematycz- 
dzi o wykorzystanie pełnego ich spektrum. Określone badania szczegółowe wiążą się z zapotrzebowaniem na specyficzną ich grupę. Skoro jednak zostaje tutaj przedstawiony warsztat teologa systematyka jako taki, potrzebne jest zarysowanie najszerszej panoramy źródeł.

Standardy metodologiczne wskazują wśród źródeł teologii najpierw na miejsca klasyczne. Są to: Pismo święte, nauczanie Kościoła, wiara Kościoła, wyrażająca się zarówno w skodyfikowanej liturgii, jak i w wielu swobodnych formach, oraz teologiczny dyskurs w jego historycznym i aktualnym wymiarze. Już sam ten zakres źródeł wskazuje na rozległość treści, do których powinny nawiązać badania teologiczne. Teolog systematyk może i powinien korzystać z nich bezpośrednio, ale na ogół nie czyni tego samodzielnie. Opiera się bowiem na szczegółowych badaniach źródłowych prowadzonych przez fachowców. W ten sposób korzystając $z$ treści biblijnych, odwołuje się do publikowanych rezultatów badań egzegetycznych, częściej jeszcze sięga na poziom pierwszych wniosków systematycznych, formułowanych w obrębie teologii biblijnej. Podobnie rzecz przedstawia się przy korzystaniu ze źródeł z historii kościelnego nauczania i teologii. Także tutaj niezbędne okazuje się nawiązanie do wyników pracy specjalistów z zakresu patrologii, mediewistyki, historii doktryny, historii duchowości i innych. Nie sposób dzisiaj prowadzić obszerniejsze badania nad tekstem historycznym bądź przeprowadzać samodzielną refleksję, opierając sie na podstawowych źródłach bez odwołania się do współczesnych publikacji, zawierających wyniki szczegółowych badań tekstu i kontekstów, propozycje rozwiązań nowych problemów, systematyzacje typów poglądów itd. Stąd w przestrzeni poszukiwanych tutaj źródeł elektronicznych pojawiają się zarówno źródła w sensie ścisłym, czyli same teksty historyczne, jak i publikowane wyniki szczegółowych badań nad nimi. Tej szerokiej drugiej dziedziny nie można pominąć przy omawianiu źródeł elektronicznych także dlatego, że to przede wszystkim ona zapełnia współczesne publikatory internetowe.

Obok wymienionej grupy sytuują się dziedziny pomocnicze dla teologii systematycznej. Należy do nich w pierwszym rzędzie filozofia, w nieomal wszystkich jej współczesnych rozgałęzieniach, a także $w$ wielu postaciach znanych $\mathrm{z}$ jej rozwoju. Dalej zaś potencjalnie dziedziną pomocniczą może okazać się każda szczegółowa dyscyplina nauki, o ile wiąże się ona z ujmowanym już teologicznie pytaniem o dany zakres rzeczywistości. Dziedziny pomocnicze pomagają najpierw w właściwym ujmowaniu i rozumieniu źródeł w sensie właściwym, czyli z pierwszej wymienionej grupy (np. historyczne i filologiczne badania nad tekstem). W dalszej kolejności okazują się niezbędne dla prowadzenia odpowiedzialnej refleksji teologicznej dzisiaj². Zaznaczam ten fakt, ale nie mogę go rozwinąć

nej przedstawia też dokument Międzynarodowej Komisji Teologicznej, Teologia dzisiaj, nr 76. Nie wchodząc w szczegółowe uzasadnienia tych rozbieżności, wystarczy tu wyjaśnić, że z punktu widzenia przedmiotu niniejszej prezentacji to szerokie rozumienie teologii systematycznej jest uzasadnione za sprawą wspólnego podejścia w tych trzech specjalizacjach do różnych typów źródeł. Różnice występują dopiero w poszukiwaniu odpowiednich treści.

${ }^{2}$ Wiele jest dziś takich żywych obszarów wymiany i dyskusji. Trudno je krótko wymieniać bez naiwnych uproszczeń, ale spróbujmy to uczynić dla uzyskania podstawowej ilustracji problemu. Są 
w niniejszym opracowaniu w odniesieniu do zagadnienia źródeł elektronicznych. Zakres dziedzin pomocniczych rozszerza się tak znacznie, że należy go wyłączyć $\mathrm{z}$ niniejszej prezentacji.

$\mathrm{Z}$ powyższych uwag dotyczących warsztatu badawczego teologa wynika logika prezentacji źródeł elektronicznych. Najpierw zostaną omówione elektroniczne zasoby najważniejszych grup dokumentów źródłowych teologii, przy czym wyłączona $\mathrm{z}$ nich zostaje prezentacja źródeł biblijnych jako dziedziny na tyle szerokiej, że domagałaby się osobnego przedstawienia ${ }^{3}$. Tym samym omówienie będzie skoncentrowane na źródłach historycznych, do których należy najpierw nauczanie Kościoła w różnych instancjach, a następnie teksty pisarzy kościelnych z całej historii chrześcijaństwa, a wreszcie świadectwa wiary, kultu, pobożności wiernych. Wśród tych ostatnich teologa zainteresują nie tylko teksty, lecz także inne świadectwa aktywności kulturalnej. Po tym przeglądzie źródeł historycznych zostanie podjęta próba przedstawienia i charakterystyki elektronicznej dostępności tekstów naukowych z zakresu teologii oraz informacji naukowej o nich. Wreszcie w uzupełnieniu tej panoramy źródeł elektronicznych zostanie zwrócona uwaga na trudne do zaszeregowania, a rozpowszechnione formy wypowiedzi w Internecie, związane z blogami i mediami społecznościowymi.

\section{Dynamika zmian. Problemy badacza}

W doświadczeniu badacza, który rozpoczynał pracę naukową w klasycznej bibliotece, dysponującej kartkowymi katalogami i drukowanymi zestawami bibliografii zawartości czasopism, jasno przedstawia się epokowa zmiana wytworzona przez rewolucję informatyczną. Jej wielka dynamika, która odmieniła także warsztat pracy teologa, sprawia, że diagnozy stawiane nawet przed niewielu laty, domagają się uzupełnień i korekt. By wskazać na ten fakt, chcę w niniejszej prezentacji jako punkt odniesienia przyjąć tekst Grzegorza Strzelczyka z 2005 r. Teologia z sieci. Kilka uwag o teologicznych zastosowaniach Internetu ${ }^{4}$. Ta praca (zapis wystąpienia na VII Kongresie Teologów Polskich w 2004 r.) z dużą znajomością przedmiotu referuje dość szeroki obraz zastosowań Internetu w warsztacie

to zatem przykładowo przestrzenie wymiany z naukami o historii w pytaniu o teologiczny wymiar tejże, z psychologią w pytaniu o duchowe sprawności człowieka, z naukami przyrodniczymi w pytaniu o rozumienie stworzenia i jego liczne aspekty, z kulturoznawstwem w pytaniu o kulturę jako miejsce realizowania się transcendentnego wymiaru życia ludzkiego.

${ }^{3}$ Prezentację tego warsztatu należałoby pozostawić teologowi bibliście. Teologowi systematykowi w znakomitej większości jego prac wystarczą w miarę proste narzędzia do poznawania tekstu biblijnego, przede wszystkim różne wydania Biblii, towarzyszące im słowniki, leksykony, a zwłaszcza komentarze biblijne, a w końcu szczegółowe opracowania w monografiach i artykułach naukowych. Reguły korzystania z tych materiałów w przestrzeni elektronicznej są takie same jak innych współczesnych prac teologicznych. O nich zaś będzie mowa nieco dalej.

${ }^{4}$ Por. G. Strzelczyk, Teologia z sieci. Kilka uwag o teologicznych zastosowaniach Internetu, w: Kościót w życiu publicznym. Teologia polska i europejska wobec nowych wyzwań. Materiaty VII Kongresu Teologów Polskich. Katolicki Uniwersytet Lubelski, 12-15 września 2004 r., t. 3: Dyskusje, komunikaty, uzupetnienia, dokumenty końcowe, red. K. Góźdź, K. Klauza i in., Lublin 2005, s. 89-101. 
teologa sprzed ponad 15 lat, a zatem, patrząc z perspektywy rozwoju tej technologii, w okresie już odległym.

Klasyczna biblioteka sprzed epoki elektronicznej rozwijała się linearnie, przez rozszerzanie księgozbioru. Informacja o zasobach z zasady nie mogła podlegać jakościowemu rozwinięciu, nawet gdy usprawnieniu podlegała komunikacja między bibliotekami. Technologie komputerowe i sieciowe radykalnie zmodyfikowały oba te obszary: dostępności tekstu naukowego (a szerzej: danych) oraz informacji o nim. Proces tych zmian trwa, i to $\mathrm{z}$ dużą intensywnością, w związku z tym także teolog staje tu przed wyzwaniami analogicznymi do tych, z którymi są skonfrontowani naukowcy z dziedziny humanistyki: poznawania i opanowania nowych technologii jako narzędzia $\mathrm{w}$ codziennej pracy. Podkreślam tu bliskość problemów dzielonych $\mathrm{z}$ reprezentantami humanistyki (to oczywiste, że rzecz najpierw dotyczy po prostu świata nauki), bo - poza ogólnymi wyzwaniami skoku technologicznego - teologa łączy z nimi specyficzny stosunek do tekstu. W pracy teologa, tak jak w pracy filozofa, historyka, filologa, chodzi o cierpliwą i uważną pracę z tekstem o bardzo często znacznej objętości. Tymczasem umożliwiony przez technologię szeroki dostęp do informacji naukowej paradoksalnie może tę pracę utrudnić. $Z$ jednej strony umożliwia on skompletowanie danych, poglądów, stworzenie mapy stanu badań na skalę wcześniej trudną do pomyślenia. $Z$ drugiej jednak strony badacz staje przez groźbą zagubienia w tekstach komentarzy i gąszczu stanowisk, które to może skłaniać do pospiesznej i niepogłębionej lektury, a w efekcie prowadzić do niepoprawnych diagnoz. Jeśli to spostrzeżenie jest słuszne, to teolog, wraz z przedstawicielami innych działów humanistyki, staje przed szeregiem wyzwań. Najpierw przed groźbą wykluczenia cyfrowego, któremu można zaradzić przez uczenie się obsługi nowych technologii i uczynienie z nich zwyczajnego narzędzia pracy. Potem zaś - przed koniecznością nowych metod oceny tekstów, które w wielkiej ilości poniekąd same trafiają na biurko. Dzięki kształceniu się w tym zakresie winien osiągnąc stan, w którym nowe technologie nie będą dla niego barierą (w przypadku braku ich znajomości) lub nie będą zatrzymywały na sobie (w przypadku jednostronnej fascynacji novum), lecz pozostając narzędziami, będą prowadziły do osiągania lepszych efektów naukowych.

$\mathrm{Na}$ koniec tego wstępnego omówienia rewolucji technologicznej i związanych z nią wyzwań dla badacza warto zwrócić uwagę na jeden szczególny aspekt nowej dostępności źródeł i tekstów naukowych, a także komunikacji naukowej, który dla teologii w Polsce ma niebagatelne znaczenie. Otóż wspomniany postęp techniczny, który rozpatrujemy od strony rozszerzenia dostępu do materiałów, stworzył także warunki ułatwiające włączenie się polskich teologów w dyskurs międzynarodowy. To dla teologii ważne, bo po odległym już wygaśnięciu epoki łaciny jako języka uniwersalnego w Kościele i teologii w nieunikniony sposób dochodziło do parcelacji sposobów uprawiania teologii na grupy językowe, a także do wymuszonej sytuacją polityczną marginalizacji środowiska teologicznego z bloku wschodniego. Teolodzy w Polsce starali się pokonywać te trudności. Przede wszystkim liczne przykłady w literaturze polskiej pokazują, że dokonywali recepcji myśli obcojęzycznej. Obecna sytuacja organizacyjna teologii w Polsce 
oraz sytuacja techniczna nauki pozwalają na dużo intensywniejsze włączenie się w dyskurs światowy. Brak jednak wciąż wyraźnych znaków takiego wzrostus.

\section{Elektroniczne zasoby dokumentów źródłowych}

\section{Nauczanie kościelne}

W obszarze elektronicznych źródeł z zakresu nauki Kościoła można wskazać zrozumiałą zasadę: im bliżej współczesnych wypowiedzi Kościoła, tym większy zasób źródeł w Internecie. Trudno zliczyć miejsca, w których pojawiają się dokumenty kościelne. Podstawowym, autoryzowanym, a zatem miarodajnym miejscem publikacji tychże dokumentów jest oficjalna strona Stolicy Apostolskiej6. Dodatkową zaletą tej lokalizacji jest paralelna publikacja dokumentów kościelnych w różnych językach, w wielu przypadkach także po polsku. Sama strona główna jest redagowana w 8 językach współczesnych (bez polskiego) oraz po łacinie. Przede wszystkim zawiera dokumentację nauczania papieskiego. W przypadku ostatnich pontyfikatów jest ona bardzo szczegółowa i tłumaczona na liczne języki. Im dalej wstecz, tym mniej jest tłumaczeń, a także uboższa oferta tekstów. W chwili redagowania tej pracy wspomniana strona zatrzymała się na prezentacji dokumentów papieża Benedykta XIV (1740-1758). Strona zawiera także pełną dokumentację nauczania Soboru Watykańskiego II (brak thumaczeń polskich), a także obie konstytucje Soboru Watykańskiego I. Dla teologa systematyka ważny jest pełnotekstowy dostęp do dokumentów Kongregacji Nauki Wiary ${ }^{7}$ (udostępnione są teksty od momentu jej głębokiej reformy i nadania obecnej nazwy w 1965 r. $^{8}$ ) oraz dostęp do opracowań Międzynarodowej Komisji Teologicznej9, istotnego ciała watykańskiego wspierającego prace Kongregacji. Wspomniane grupy dokumentów są najważniejsze z punktu widzenia teologa systematyka, ale nie wyczerpują szczegółowych obszarów jego zainteresowania nowszymi kościelnymi źródłami. Sama strona watykańska zawiera wiele dalszych dokumentów źródłowych, przyporządkowanych zwłaszcza do różnych jednostek organizacyjnych Kurii Rzymskiej. Na koniec trzeba stwierdzić, że na stronie watykańskiej nie zabrakło kompletnego zestawu oficjalnych akt Stolicy Apostolskiej: Acta Apostolicae Sedis, a wcześniej Acta Sanctae Sedis.

Ważnym narzędziem w pracy teologa jest wykaz wypowiedzi nauczycielskich Kościoła opracowany przez Heinricha Denzingera i po raz pierwszy opublikowany drukiem w roku $1854^{10}$. Doczekał się on do chwili przygotowania tego opra-

${ }^{5}$ Badania przeprowadzone przez Emanuela Kulczyckiego nie potwierdzają wyraźnego wzrostu publikacji zagranicznych w dyscyplinie nauki teologiczne w latach 2013-2016. Por. E. Kulczycki, Wzory publikacyjne polskich naukowców w latach 2013-2016. Nauki humanistyczne i spoleczne, http://hdl.handle.net/10593/24460 (dostęp: 12.03.2020), s. 290-291.

${ }^{6}$ w2.vatican.va (dostęp: 7.03.2020).

${ }^{7} \mathrm{http}: / /$ www.vatican.va/roman_curia/congregations/cfaith/doc_doc_index.htm (dostęp: 7.03.2020).

${ }^{8}$ Por. Congregation for the Doctrine of the Faith - Profile, http://www.vatican.va/roman_curia/ congregations/cfaith/documents/rc_con_cfaith_pro_14071997_en.html (dostęp: 07.03.2020).

${ }^{9} \mathrm{http}: / /$ www.vatican.va/roman_curia/congregations/cfaith/cti_index.htm (dostęp: 7.03.2020)

${ }^{10}$ Por. H. Denzinger, P. Hünermann, Enchiridion symbolorum definitionum et declarationum de rebus fidei et morum. Kompendium der Glaubensbekenntnisse und kirchlichen Lehrentscheidungen, Freiburg, Basel, Wien 1991, s. 3. 
cowania 45 wydań, wielokrotnie rozbudowywanych, doskonalonych, zaopatrywanych w coraz obszerniejsze, szczególnie cenne indeksy. Niestety, wciąż nie ma tej epokowej pracy w bazach internetowych, w postaci bazy danych. Wydawnictwo Herder udostępniało natomiast wraz książką płytę CD z wersją elektroniczną tekstu, ostatnio zaś możliwy jest zakup e-booka (PDF) ${ }^{11}$. Także pochodne „Denzingera” nie doczekały się digitalizacji lub też - jak w przypadku polskiego wydania „Breviarium Fidei”" 12 - próba ta nie okazała się w pełni udana ${ }^{13}$. W tej części opisu źródeł elektronicznych można zatem wysnuć prosty wniosek technologiczny: o potrzebie przygotowania solidnej bazy danych. Natura tego typu źródła (bardzo obszerny zakres danych i wielość zagadnień, które można poddać wielopoziomowej indeksacji) sprzyja zastosowaniu takiej właśnie technologii. Od strony merytorycznej mogą jednak budzić się uzasadnione obawy związane z ewentualnym wytworzeniem takiego narzędzia. Zgłaszano je już w teologii wielokrotnie w odniesieniu do niewłaściwego traktowania drukowanego „Denzingera" jako gotowego zbioru wypowiedzi doktrynalnych Kościoła ${ }^{14}$. Dzieło to łatwo może zwieść w stronę poddania się lekturze, która nie uwzględnia zmieniających się kontekstów powstawania odnośnych fragmentów, a także zapomina o tym, że wciąż chodzi tu o wybór. Można zakładać, że stworzenie narzędzia elektronicznego o charakterze „Denzingera” łatwo pogłębiłoby ten problem recepcji. Nie zmienia to jednak faktu, że (doskonalony i powiększany) wybór wypowiedzi doktrynalnych Kościoła stanowi po prostu zbiór danych, niezbędnych w badaniach teologiczno-systematycznych. Jako taki stanowi materię wyjściową do pracy naukowej, która m.in. dopiero uwzględni odpowiednie konteksty historyczne. Nie jest zaś podręcznikiem. $Z$ pewnością odważna próba wykorzystania wszystkich

${ }^{11}$ Por. H. Hoping, P. Hünermann, Kompendium der Glaubensbekenntnisse und kirchlichen Lehrentscheidungen. Enchiridion symbolorum definitionum et declarationum de rebus fidei et morum. Verbessert, erweitert, ins Deutsche übertragen und unter Mitarbeit von Helmut Hoping herausgegeben von Peter Hünermann, Freiburg 2017. Można usprawiedliwiać brak wydania „Denzingera” w formie bazy danych tym, że nowsze wydania książkowe są wyposażone w znakomite indeksy, obejmujące ponad 200 stron.

${ }^{12}$ Por. S. Głowa, I. Bieda, Breviarium fidei. Wybór doktrynalnych wypowiedzi Kościoła, Poznań 1997. Nowa, przeredagowana i uzupełniona wersja: I. Bokwa, Breviarium fidei. Wybór doktrynalnych wypowiedzi Kościoła, Poznań 2007.

${ }^{13}$ W 2003 r. Wydawnictwo M opublikowało dysk CD (Ł. Gwóźdź, J. Strojek, A. Hajda, Nauczanie Kościoła katolickiego, Kraków 2003), który zawierał następujące teksty: Pismo Święte z komentarzami, Breviarium Fidei - wybór najważniejszych orzeczeń doktrynalnych Kościoła, Nauczanie papieży, Kodeks Prawa Kanonicznego, Teksty Soboru Watykańskiego II, Praktyczny komentarz do Nowego Testamentu, Słowniki (m.in. pisarzy chrześcijańskich, leksykon papieży), Kalendaria, Indeksy (wg opisu sprzedawcy www.kmt.pl). Zawartość tekstowa została udostępniona przy pomocy odpowiedniego programu, który umożliwiał wyszukiwanie według różnych, także zaawansowanych kryteriów. O ile strona techniczna została dopracowana, to same teksty zawierają wiele błędów literowych i przekłamań. Sprawdzałem wraz ze studentami pod tym kątem jakość tekstu Breviarium Fidei oraz nauczania Jana Pawła II. Problem przypuszczalnie powstał w procesie skanowania drukowanych tekstów i poddawania go procesowi OCR; zabrakło końcowej korekty.

${ }^{14}$ Por. K. Rahner, Dogmen- und Theologiegeschichte - Gestern und Morgen, „Zeitschrift für Katholische Theologie", 99,1 (1977) s. 12. 
zalet technologii elektronicznych pozwoliłaby wykroczyć poza ograniczenia, jakie narzuca forma drukowana.

Przykładem takiego ambitnego podejścia do źródeł, ale programowo zawężonych do nauczania Jana Pawła II, jest rodzima baza „ZIBATEPA”, redagowana przez Centrum Myśli Jana Pawła II i portal opoka.org.p $1^{15}$. Dzięki niej z łatwością można poruszać się w różnych tematach nauczania papieskiego, w rosnącym zbiorze tekstów.

\section{Teksty pisarzy kościelnych}

Udostępnienie ogromnych zasobów źródeł z historii teologii w postaci krytycznych edycji dzieł i często ich tłumaczeń na wiele języków stanowi niewątpliwie epokowe osiągnięcie z zakresu badań nad historią teologii. Postępujące ich udostępnianie w sieci Internet przebiega na różnych drogach, co oczywiście każe pytać o wiarygodność poszczególnych miejsc, jak i o zgodność z obowiązującymi prawami autorskimi. Zajmę się tu jedynie przykładami serwisów wiarygodnych, a więc takich, które tworzone są przez uznane instytucje naukowe oraz naukowe wydawnictwa. Praktyka pokazuje jednak, że nie należy przy tym lekceważyć prywatnych stron internetowych naukowców, chociaż wówczas potrzebne jest stosowanie dodatkowych kryteriów oceny zamieszczanych tekstów.

$\mathrm{W}$ procesie udostępniania $\mathrm{w}$ Internecie tekstów $\mathrm{z}$ historii teologii można zaobserwować dwie zasadnicze strategie. Jedną prezentują wydawnictwa naukowe; udostępniają one swoje serie opublikowanych źródeł, obejmujące zwykle szerokie spektrum czasu i autorów. Drugą ścieżką idą instytucje wyspecjalizowane w węższym zakresie. Te prezentują wyniki własnych prac ze źródłami, często skoncentrowane na jednym autorze albo umieszczają linki do stron innych podmiotów, udostępniających interesujące źródła z tego zakresu.

Zacznijmy od drugiej grupy. Instytucje naukowe tworzyły swoje serwisy internetowe już w relatywnie wczesnej fazie rozwoju Internetu. Stąd wspominany raport G. Strzelczyka z 2004 r. omawia kilka przykładów istniejących już wówczas i funkcjonujących do dziś serwisów, udostępniających teksty klasyków $\mathrm{z}$ historii teologii w postaci gotowych tekstów lub baz danych: Augustyna, Tomasza z Akwinu, Marcina Lutra, Henry'ego Newmana ${ }^{16}$. Dziś znacznie wzrosła ich liczba. Teolog poszukujący konkretnych tekstów źródłowych, jeśli posługuje się podstawową wyszukiwarką, łatwo na nie natrafia, ale też natychmiast zostaje skonfrontowany z problemem ich jakości i wiarygodności. Na pierwszy rzut oka może rozpoznać znaczne różnice między ofertami. Pozostańmy przy trzech przykładach. W odniesieniu do serwisu „The Franciscan Archive"17, zawierającego

15 Zob. http://www.nauczaniejp2.pl/o-aplikacji (dostęp 28.02.2020). Tam też znajduje się krótka informacja o zawartości: „Aktualna wersja aplikacji zawiera komplet: wszystkich encyklik i adhortacji Jana Pawła II, Jego orędzi i wystąpień z okazji Światowych Dni Młodzieży, homilii i przemówień z pielgrzymek do Ojczyzny oraz wybrane przemówienia i homilie z niektórych (od roku 1997) pielgrzymek zagranicznych Jana Pawła II. Dokumenty są zintegrowane ze specjalnie przygotowanym indeksem pojęć, miejsc, osób i odwołań bibliograficznych”.

${ }^{16}$ Strzelczyk, Teologia z sieci, s. 93.

${ }^{17}$ franciscan-archive.org (dostęp: 28.02.2020). 
m.in. teksty franciszkańskich teologów (lub odnośniki do innych serwisów), trudno o jednoznaczne ustalenie stopnia powiązania instytucjonalnego z zakonem lub jego naukową agendą. W poszukiwaniu tekstów Suareza łatwo jest znaleźć stronę projektu naukowego zawierającego efekty digitalizacji dzieła tego teologa ${ }^{18}$. Autor strony nie informuje o przekazaniu dzieła do innego serwisu ${ }^{19}$. Prawdopodobnie zatem jedyną drogą do tej treści jest standardowa wyszukiwarka. Z kolei badacz poszukujący tekstów Augustyna i wiedzy o jego teologii, posiadając już podstawową wiedzę o ośrodkach badawczych, z łatwością znajdzie m.in. stronę Zentrum für Augustinusforschung Uniwersytetu w Würzburgu ${ }^{20}$, zaopatrzoną w krytyczną edycję tekstów, bazy źródeł i literatury pomocniczej, dostęp do leksykonu i inne.

Poszukiwanie dostępu do źródeł „na własną rękę” wiąże się z obowiązkiem krytycznej oceny znalezionych publikatorów internetowych. Ocena ta nie zawsze jest łatwa; samo przypisanie strony zawierającej teksty do instytucji cieszącej się autorytetem naukowym nie zwalnia z konieczności głębszego przeanalizowania szeregu problemów wpływających na ocenę jakości serwisu. Częsty brak dochowania standardów typowych dla prac publikowanych drukiem (wskazanie procesu recenzyjnego, jednoznaczna tożsamość instytucji lub osoby publikującej tekst, a nawet wciąż, choć rzadziej, występujący problem deklaracji praw autorskich) domaga się - nie zawsze łatwych - dodatkowych analiz wstępnych. Łatwość ,zawieszenia" tekstu w Internecie, która jest zaletą w przypadku szybkiej publikacji $\mathrm{np}$. w repozytoriach uczelnianych wyników badań prowadzonych w ramach nauk eksperymentalnych, niekoniecznie służy najwyższej jakości publikacji w przypadku edycji źródeł.

Trzeba wreszcie wspomnieć, że kontynuacja takiej samodzielnej drogi poszukiwania źródeł prowadzi dalej do zbiorów odnośników do tekstów źródłowych, tworzonych na stronach uczelnianych bibliotek, niekiedy zbieranych na prywatnych stronach przez naukowców, innym razem przez amatorów. Zwykle wykazy prywatne nie nadążają za aktualizacjami adresów, a przede wszystkim pogłębiają problem oceny wiarygodności stron, gdyż dziedziczą wyżej wspomniane trudności, a ponadto nie różnicują między tymi znaleziskami. Są wśród nich mimo to prace niezwykle pomocne ${ }^{21}$.

Zasadniczo bezpieczną drogę dostępu do źródeł prezentują wydawcy uznanych serii, którzy przenoszą do nowego obszaru eksploatacji, jakim jest Internet, swoje edycje źródeł przygotowane dotąd w postaci drukowanej i kontynuowa-

$18 \mathrm{http} / /$ homepage.ruhr-uni-bochum.de/Michael.Renemann/suarez/index.html (dostęp: 28.02.2020).

${ }^{19}$ Poza prywatną stroną współuczestnika projektu: http://www.salvadorcastellote.com/investigacion.htm (dostęp: 28.02.2020).

${ }^{20}$ www.augustinus.de (dostęp: 28.02.2020).

${ }^{21}$ Do takich zaliczyć można patristica.net, zawierający m.in. uporządkowane odnośniki do wszystkich tomów standardowego XIX-wiecznego dzieła Migne'a Patrologiae Cursus Completus. Tomy rozproszone są w zbiorach Google Books i archive.org. Interesującym projektem jest także serwis Corpus Scriptorum Latinorum (http://www.forumromanum.org/literature/index.html). Autorzy serwisu zapewniając o staranności doboru publikacji, proszą czytelników o krytyczne uwagi dotyczące jakości tekstów. 
ne. Edycje elektroniczne dziedziczą tutaj autorytet naukowy od wydawcy, stosującego zaawansowane metody weryfikacji swoich publikacji. Oczywistą formą publikacji elektronicznej jest przygotowanie ebooków, identycznych w układzie $\mathrm{i}$ treści $\mathrm{z}$ wersją drukowaną ${ }^{22}$. Równocześnie uznane wydawnictwa naukowe, dysponujące dużą liczbą wydanych tekstów, przygotowują odpowiednie bazy danych. Tytułem przykładu zatrzymuję się tylko przy jednej ofercie tego typu. Wzorcowy charakter w odniesieniu do źródeł interesujących teologa systematyka ma m.in. Wydawnictwo Brepols. Pod osobnymi adresami przedstawia ono dostęp do swoich ebooków i e-czasopism ${ }^{23}$ oraz baz danych ${ }^{24}$. Wśród wielu usług (a podkreślić należy rozpoczęcie udostępniania jako bazy danych wielkiej serii „Sources Chrétiennes” 25 oraz najnowszych tomów serii „Corpus Christianorum in Translation"26 i wielu innych) warto zauważyć rozpoczynającą działanie bazę „Clavis clavium”27, która pozwala połączyć sprawność elektronicznego systemu wyszukiwania z bogatymi zasobami drukowanych prac źródłowych. Podobnie działają inne cenione wydawnictwa publikujące serie źródłowe interesujące także dla teologa: deGruyter, Brill, Mohr Siebeck i inne. Przedstawienie strategii działania każdego z nich na polu źródeł elektronicznych wykracza poza ramy tego opracowania.

\section{Świadectwa pobożności i kultury religijnej}

Innym znaczącym, a obszarowo bardzo rozległym działem historycznych źródeł teologii są przejawy życia religijnego, które nie znalazły się (jeszcze) w kanonach rozpraw teologicznych, a ujawniają się w różnych pamiątkach kultury. Chodzi tu przede wszystkim o źródła służące zgłębianiu stanu wiary chrześcijan na jakimś etapie historii. W takiej sytuacji Internet stanowi olbrzymi rezerwuar materiałów zawierających zwykle skany tekstów teologicznych, katechizmów, modlitewników, pamiętników, zapisków, a dalej także rysunków, obrazów, rzeźb, filmów itd. Teolog zainteresowany takimi poszukiwaniami ma do dyspozycji wielką liczbę bibliotek cyfrowych, gromadzących najrozmaitsze pamiątki kultury. W zakresie gromadzenia tekstów z dziedziny religioznawstwa i teologii na gruncie polskim nie sposób pominąć Księgozbioru Wirtualnego Federacji FIDES ${ }^{28}$. Wielkie usługi oddają tu tak samo inne polskie biblioteki cyfrowe. Tym samym najlepszym narzędziem do wyszukiwania tego typu źródeł, niezależnie od tego,

${ }^{22}$ Wskazywana przez naukowców potrzeba tożsamości wersji elektronicznej z drukowaną prowadzi do preferowania formatu PDF. Współczesne propozycje wydawców upowszechnienia formatów ePUB i mobi (oraz pochodnych) natrafiają wśród naukowców na trudności właśnie ze względu na nierozwiązany ostatecznie problem tożsamości paginacji tych wydań z wersją drukowaną.

${ }^{23}$ Brepolsonline.net (dostęp: 28.02.2020).

${ }^{24}$ Brepolis.net (dostęp: 28.02.2020).

${ }^{25} \mathrm{https}$ ///about.brepolis.net/sources-chretiennes-online-sco/ (dostęp: 6.03.2020)

${ }^{26} \mathrm{https}$ ://www.brepolsonline.net/series/cct-eb (dostęp: 6.03.2020)

${ }^{27} \mathrm{https}$ ://clavis.brepols.net/clacla/Default.aspx (dostęp: 28.02.2020).

${ }^{28}$ Księgozbiór Wirtualny Federacji Bibliotek Kościelnych FIDES, http://digital.fides.org.pl/ dlibra (dostęp:06.03.2020). Por. J. Witczak, Teologiczne zbiory w polskich bibliotekach cyfrowych, „Fides: Biuletyn Bibliotek Kościelnych”, 24-25 (2007) nr 1-2, s. 24-34. 
że dotyczy to tak samo współczesnych tekstów naukowych, jest Federacja Bibliotek Cyfrowych, która w jednej wyszukiwarce pozwala znaleźć odpowiednie zbiory $^{29}$. Natomiast jeśli chodzi o zasoby światowe, istotną pomoc przynosi Open Access Digital Theological Library ${ }^{30}$. Badacz poszukujący tego typu materiałów nie może pozostać przy wymienionych zbiorach tylko dlatego, że są związane tematycznie $z$ religią. Ze względu na rozproszenie takich materiałów i ich niełatwą klasyfikację powinien starać się korzystać także z innych bibliotek cyfrowych, udostępniających zdigitalizowane wersje świadectw kultury ${ }^{31}$. W większości te wymienione zbiory wirtualne obejmują równocześnie publikacje najnowsze, dlatego pojawią się w tej prezentacji raz jeszcze.

\section{Elektroniczne zasoby wspólczesnych tekstów teologicznych}

Prezentacja w tym dziale nie będzie odpowiadać kanonom systematyzacji źródeł elektronicznych właściwym dla informacji naukowej. Te są znane z innych opracowań. W niniejszym przedstawieniu, nastawionym na zdanie sprawy z poszukiwań badacza poznającego stopniowo świat źródeł elektronicznych, ważne wydaje się raczej odtworzenie etapów przechodzenia od biblioteki „tradycyjnej” do współczesnej jej postaci i odkrywania tym samym kolejnych poziomów złożoności tej nowoczesnej sieci informacji naukowej.

W badaniach nad źródłami, jak i w bieżącej dyskusji z zakresu teologii systematycznej ważna jest oczywiście znajomość stanu badań, zasobów argumentacji, spektrum poglądów. W tym celu niezbędny jest sprawny dostęp zarówno do monografii, jak i do artykułów w czasopismach i rozdziałów w pracach zbiorowych. Oczywistą podstawową pomoc w tym zakresie stanowią elektroniczne katalogi zbiorów bibliotecznych. Oczywiście, trudno już jest dziś korzystać wyłącznie $\mathrm{z}$ jednolitej biblioteki tekstów drukowanych. $\mathrm{Na}$ rosnącym w wielkim tempie rynku tekstów naukowych coraz większy udział mają publikacje elektroniczne, a stąd coraz większą pomocą służą bazy gromadzące informacje bibliograficzne z obu tych obszarów: druku i mediów elektronicznych, a w końcu także te, które udostępniają te publikacje. Pod tym względem sytuacja teologii prawdopodobnie niczym nie różni się od sytuacji innych nauk humanistycznych. Niemniej jednak w humanistyce (a więc i teologii) wciąż wielką rolę odgrywają publikacje drukowane. Dlatego, na miarę tej roli, pierwszą funkcją mediów elektronicznych jest dostarczenie wyczerpującej informacji o poszukiwanych tytułach ${ }^{32}$. W ten sposób

\footnotetext{
${ }^{29} \mathrm{http}: / /$ fbc.pionier.net.pl/.

${ }^{30}$ Por. B.M. Morawiec, Biblioteki cyfrowe. Tworzenie, zarządzanie, odbiór, Gliwice 2016

${ }^{31}$ Do wartościowych, bardzo obszernych projektów o międzynarodowym zasięgu można zaliczyć europeana.eu i archive.org.

${ }^{32}$ Powyższa opinia o pierwszeństwie prac drukowanych w badaniach może wydać się sporna i jej ocena ostatecznie może się sprowadzać do pewnych nawyków naukowca, związanych z wygodą czytania - sprawą istotną przy lekturze długich tekstów, które w całej humanistyce mają fundamentalne znaczenie. Jak się okazuje i tutaj jednak zachodzą zmiany, tzn. spada udział monografii w cytowaniach w humanistyce. Por. T.C.E. Engels, A.I. Starčič, E. Kulczycki, J. Pölönen, G. Sivertsen, Are book publications disappearing from scholarly communication in the social sciences and humanities?, https://repozytorium.amu.edu.pl/bitstream/10593/24097/1/STI2018_paper_132.pdf
} 
ze szczególną pomocą przychodzą bazy bibliograficzne, łączące katalogi wielu bibliotek. Tu w przestrzeni ważnej dla teologa niezastąpioną rolę w udostępnianiu zawartości polskich bibliotek kościelnych odgrywa zbiorczy Centralny Kata$\log$ Bibliotek FIDES, przekazujący obecnie informacje z 23 bibliotek $^{33}$. Zawsze przydatny okazuje się dostęp do katalogów szerokiego spektrum bibliotek naukowych w Polsce poprzez zbiorczy katalog NUKAT ${ }^{34}$, z którym Federacja FIDES współpracuje. W końcu dla skompletowania wiedzy o stanie badań na dany temat w przestrzeni polskiej literatury zawsze ważne jest przeszukanie zawartości katalogu Biblioteki Narodowej ${ }^{35}$. Podobnie może być w odniesieniu do bibliotek zagranicznych. Poszukiwania umożliwiają odpowiednie agendy na poziomie danego kraju. W skali światowej zaś ostatecznie umożliwia poszukiwania Worldcat - największa światowa baza bibliograficzna, oferująca m.in. połączone wyszukiwanie w katalogach tysięcy bibliotek na świecie ${ }^{36}$.

W tym miejscu należałoby przejść do charakterystyki baz zawartości czasopism i prac zbiorowych. Podejmując jednak temat korzystania $\mathrm{z}$ czasopism w sieci internetowej, warto wykonać jedną dygresję i wrócić do opisu pewnych przyzwyczajeń, ukształtowanych w tradycyjnej bibliotece, które potrafią nadal oddziaływać. Otóż wspominany tu czytelnik-naukowiec, o ile z trudem przechodzi w świat wirtualny, z wdzięcznością powita znajome czasopisma w postaci zdigitalizowanej, zamieszczone w komplecie pod jednym adresem internetowym. Ma to szczególne znaczenie, gdy redakcja w ostatnim czasie przeniosła czasopismo głównie bądź wyłącznie do Internetu. W ten sposób w sieci zostaje zapewniona kompletna dokumentacja: zarówno nowsze zeszyty (tomy) publikowane już w formie elektronicznej, jak i zdigitalizowane egzemplarze historyczne ${ }^{37}$.

Wielka liczba ofert tekstów w formie elektronicznej ważnych dla teologa nie pozwala zajmować się tutaj pojedynczymi tytułami czasopism czy wydawnictwami, jakkolwiek godne uwagi byłoby prześledzenie różnych indywidualnych strategii związanych $\mathrm{z}$ wchodzeniem w przestrzeń cyfrową. Osoba zainteresowana dostępem do polskiej literatury fachowej przez przeglądanie kolejnych tytułów z zakresu swojej dyscypliny może skorzystać z praktycznego narzędzia, jakim jest baza arianta.pl, starannie rozwijana i aktualizowana. Znajdzie tam wiele użytecz-

(dostęp: 28.02.2020). Na temat konieczności zmian przyzwyczajeń i służących temu technicznych pomocy staram się podać kilka subiektywnych uwag na końcu tekstu.

${ }^{33} \mathrm{https}$ ://katalog.fides.org.pl/ (dostęp: 24.04.2020).

${ }^{34} \mathrm{http}: / /$ katalog.nukat.edu.pl.

${ }^{35} \mathrm{https}: / /$ katalogi.bn.org.pl.

${ }^{36}$ Por. https://www.worldcat.org/whatis/default.jsp (dostęp: 20.04.2020)

${ }^{37}$ Wzorcowe rozwiązania $\mathrm{w}$ tym zakresie przedstawia m.in. projekt Biblioteki Uniwersytetu w Tybindze o nazwie DigiTheo (http://idb.ub.uni-tuebingen.de/digitue/theo; dostęp: 03.03.2020). $\mathrm{W}$ jego ramach zdigitalizowano obok licznych monografii z XIX wieku m.in. 22 tytuły czasopism teologicznych wychodzących od XIX wieku, wśród nich najstarsze, wpływowe „Theologische Quartalschrift", ukazujące się do dzisiaj. Także w Polsce wśród czasopism teologicznych, które wychodzą od wielu dekad, kilka udostępnia kompletne bądź niemal kompletne archiwa cyfrowe. Należą do nich „Collectanea Theologica” (od 1921), „Znak” (od 1946), „Ruch Biblijny i Liturgiczny” (od 1948), „Śląskie Studia Historyczno-Teologiczne” (od 1968), „W drodze” (od 1973), „Przegląd Tomistyczny" (od 1984). 
nych informacji na temat czasopisma, takich jak adres internetowy, szczegółowe dane na temat dostępności tekstów, reprezentowana dyscyplina, punktacja i inne ${ }^{38}$.

Po tej małej dygresji pora wrócić do samych baz analitycznych. Są one niezwykle ważnym narzędziem służącym w pozyskaniu informacji bibliograficznej, jako że prezentują dane o zawartości czasopism i monografii zbiorowych, umożliwiając różne strategie wyszukiwania. $Z$ punktu widzenia teologa (nie tylko systematyka) poszukującego najpierw prac dostępnych w polskich bibliotekach teologicznych w wersji papierowej bądź cyfrowej wyróżnia się tutaj kolejna baza online Federacji Bibliotek Kościelnych FIDES, jaką jest Elektroniczna Bibliografia Nauk Teologicznych. Podstawowy opis tej bazy bibliograficznej znajduje się na własnej stronie serwisu. Poszerzone wnikliwe przedstawienie jej roli w badaniach historyczno-teologicznych można znaleźć w opracowaniu Agaty Muc ${ }^{39}$. Siła tego narzędzia leży w stopniu zaangażowania $\mathrm{w}$ jego tworzenie środowisk bibliotek teologicznych w Polsce. Nawet jeśli jeszcze sporo zostaje do zrobienia, zwłaszcza na polu uzupełniania danych archiwalnych ${ }^{40}$, to liczba 139000 opisów bibliograficznych reprezentujących 230 tytułów czasopism oraz 520 tytułów prac zbiorowych wskazuje na zaawansowany stan prac, a tym samym oddaje do ręki teologa solidne narzędzie ${ }^{41}$.

W odniesieniu do teologicznych tekstów zagranicznych trzeba wymienić rozbudowany i znakomicie działający serwis ixtheo.de prowadzony przez Bibliotekę Uniwersytetu w Tybindze, obejmujący bibliografię z zakresu teologii i religioznawstwa. Wyszukiwarka działa w wolnym dostępie. Wskazuje ponad 2 miliony skatalogowanych pozycji. Baza zawiera opisy bibliograficzne artykułów z 1533 czasopism $^{42}$, a także z prac zbiorowych. Obejmuje także monografie jedno- i wieloautorskie. Zatem w jednej bazie o szerokim zasięgu, bo obejmującej pozycje różnych typów, publikowane w różnych krajach, można prowadzić poszukiwania według szerokiego zestawu kryteriów. Podobną usługę świadczy American Theological Library Association (ATLA). Dostęp do jej zasobów wymaga wykupienia subskrypcji. Ale instytucja ta oferuje nie tylko bazę bibliograficzną (ATLA Religion Database ${ }^{43}$ ), lecz także bazę pełnotekstową (ATLA Serials i ATLA Serials Plus). Ta ostatnia (w wersji „Plus”) indeksuje i udostępnia teksty z ponad 500

${ }^{38}$ Por. A. Drabek, A. Pulikowski, Możliwości wykorzystania bazy „ARIANTA” na przykładzie bibliotekoznawstwa i informacji naukowej, w: Zarzadzanie informacja w nauce, red. D. Pietruch-Reizes, W. Babik i in., s. 147.

${ }^{39}$ Por. Agata Muc, Elektroniczna Bibliografia Nauk Teologicznych jako źródto do badań historyczno-teologicznych, „Archiwa Biblioteki i Muzea Kościelne”, 9 (2018) s. 299-314.

${ }^{40}$ Por. tamże, s. 311.

${ }^{41}$ Tylko na marginesie zaznaczam, że obecność rekordów analitycznych w innych bazach, począwszy od Centralnego Katalogu „Fides”, nastręcza badaczowi trudności w interpretacji relacji między wynikami wyszukiwań w tymże katalogu i w EBNT.

${ }^{42}$ Tak wskazuje wykaz czasopism z 24 lipca 2019. Por. https://www.ixtheo.de/docs/ixtheo-journals.pdf (dostęp: 27.02.2020).

43 Atla Religion Database, https://www.atla.com/research-tool/atla-religion-database/ (dostęp:06.02.2020) 
czasopism, z ponad 35 krajów ${ }^{44}$. Baza bibliograficzna obejmuje w całości ponad 2300 czasopism, z czego ponad 1000 jest aktualnie indeksowanych ${ }^{45}$.

Obok tych dziedzinowych baz bibliograficznych (a w ostatnim wymienionym przypadku także pełnotekstowych) teolog systematyk może z powodzeniem sięgać także do baz o szerszym spektrum, szczególnie wartościowych z tego względu, że nie tylko gromadzą dane bibliograficzne, ale są bibliotekami zamieszczającymi teksty na swoich serwerach. Interesujące z punktu widzenia teologa publikacje w wolnym dostępie są prezentowane przez The Central European Journal of Social Sciences and Humanities (CEJSH) ${ }^{46}$, Directory of Open Access Journals $(\text { DOAJ })^{47}$. Na podobnych zasadach wolnego dostępu do tekstów działa polska BazHUM $^{48}$, obejmująca polskie czasopisma humanistyczne. Natomiast The Central and Eastern European Online Library $(\mathrm{CEEOL})^{49}$ przedstawia zarówno teksty odpłatne, jak i w wolnym dostępie. Odpłatną formę udostępniania przedstawia JSTOR $^{50}$. Przy tym jednak ten ostatni, oferując konkretne kolekcje czasopism, daje możliwość de facto korzystania $\mathrm{z}$ baz dziedzinowych.

Na przedłużeniu wspomnianych baz pełnotekstowych trzeba wymienić repozytoria instytucjonalne, np. uczelniane, które dynamicznie się rozwijają. Odgrywają one znaczącą rolę w realizacji zasady otwartego dostępu. Deponowane są $\mathrm{w}$ nich prace $\mathrm{w}$ celu dalszego rozpowszechniania oraz archiwizacji. Zasadniczo umieszcza się w nich teksty naukowców reprezentujących dany ośrodek. Wśród nich znajdują się zarówno recenzowane artykuły, rozdziały, monografie (postprinty), jak i niepublikowane i nierecenzowane teksty (preprinty) w różnej postaci. Najliczniejszą grupę stanowią artykuły z czasopism, prace doktorskie. Deponowane są także materiały dydaktyczne, surowe dane badawcze oraz sprawozdania i raporty ${ }^{51}$.

Przy takiej mnogości typów baz elektronicznych pełnotekstowych i bibliograficznych bardzo pomocne okazują się multiwyszukiwarki, oferowane przez instytucje, pozwalające przy pomocy jednego interfejsu poszukiwać informacji

${ }^{44} \mathrm{https} / / /$ www.atla.com/research-tool/atlas-plus/ (dostęp: 04.03.2020).

${ }^{45} \mathrm{https}: / /$ www.atla.com/research-tool/atla-religion-database/ (dostęp: 04.03.2020).

${ }^{46} \mathrm{http}: / /$ cejsh.icm.edu.pl

${ }^{47} \mathrm{https}$ ://doaj.org/ Więcej na temat obecności czasopism teologicznych w DOAJ w artykule już w zasadzie o wartości archiwalnej: E. Olszowy, Czasopisma z zakresu nauk teologicznych w bazie Directory of Open Access Journals (DOAJ), „Fides: Biuletyn Bibliotek Kościelnych”,1-2 (2010) s. $108-139$.

${ }^{48}$ http://bazhum.muzhp.pl/. Prezentacja bazy - także o historycznym już charakterze - znajduje się w tekście: Por. M.T. Szczepański, Cyfrowa kolekcja czasopism humanistycznych (Bazhum) http://www.muzhp.pl/bazhum, „Przegląd Historyczny”, 101 (2010) nr 1, s. 101-106.

${ }^{49} \mathrm{https}: / /$ www.ceeol.com/

${ }^{50} \mathrm{https}: / /$ www.jstor.org/

${ }^{51}$ Więcej na temat repozytoriów instytucjonalnych por. L. Mikołajuk, Repozytorium instytucjonalne jako nowa forma komunikacji naukowej, „Podkarpackie Studia Bibliologiczne”, 3 (2014), http://dspace.uni.lodz.pl/xmlui/bitstream/handle/11089/5071/repozytorium_instytucjonalne_1. pdf? sequence=1\&isAllowed=y oraz E. Głowacka, Polskie repozytoria instytucjonalne jako miejsce dla otwartych zasobów naukowych i edukacyjnych, „Zagadnienia Informacji Naukowej”, 54 (2016) nr 1 (107), s. 44-54. 
w różnych bazach, które dana instytucja posiada bądź subskrybuje. Specjalizują się w tym biblioteki uczelni wyższych i instytutów naukowych.

W ten sposób wyłania się nowy obraz pracy naukowca, w tym także teologa. Usprawiedliwia on m.in. widoczne odchodzenie od monotematycznych prac zbiorowych, wydawanych drukiem. Ich redagowanie do niedawna miało głęboki sens, gdyż pozwalało za pomocą książki uzyskać większą widzialność szczegółowych rozwiązań jakiegoś problemu, które w rozproszeniu mogłyby pozostać niezauważone. Panująca obecnie możliwość wyszukiwania tekstów na dany temat $\mathrm{w}$ miejscach bardzo od siebie odległych sprawia, że to sama baza danych, po użyciu odpowiedniej strategii wyszukiwania, niejako konstruuje monotematyczną ,pracę zbiorową" - a precyzyjniej: daje dostęp do szerokiego spektrum tekstów różnego typu na wybrany temat.

\section{Serwisy społecznościowe}

Rozwijająca się sfera kontaktów między naukowcami za pośrednictwem wyspecjalizowanych portali wymiany naukowej ${ }^{52}$ odkrywana jest także przez teologów. To zjawisko specyficzne dla kolejnego etapu rozwoju Internetu, zwane „nauka 2.0 " 53 . Badanie w tym zakresie aktywności przedstawicieli nauk humanistycznych, społecznych i teologicznych przeprowadzone (na danych z 2015 r.) przez M. Hołowieckiego wykazało, że teolodzy stanowią grupę mało aktywną na tym polu ${ }^{54}$. Nieusystematyzowana obserwacja własna pozwala mi wysuwać hipotezę, że - ujmując w liczbach bezwzględnych - sytuacja ta zmieniła się w ciągu ostatnich 5 lat, czyli od czasu przeprowadzenia tych badań. Ujmując zjawisko od strony warsztatu badawczego teologa, możliwość nawiązania kontaktu i faktycznej współpracy badawczej z osobami z całego świata jest nie do przecenienia. Wydaje się, że pierwszym krokiem do takiej współpracy jest sama możliwość korzystania z tekstów udostępnianych przez specjalistów realizujących podobne badania.

Pewną płaszczyzną wymiany są też blogi czy też innego typu serwisy internetowe prowadzone przez indywidualnych autorów. Ten typ aktywności najbardziej wymyka się formalizacji, ale może stanowić bogate źródło inspiracji. Treści tam przedstawiane nie są z konieczności podporządkowane rygorom tekstów naukowych, co oznacza, że mogą mieć charakter popularyzatorski albo preferować formy eseju, dyskusji, krótkiej notatki i inne. Jest zatem jasne, że ta forma publikacji internetowych domaga się uważnej oceny wartości i poziomu prezentowanych treści ${ }^{55}$. W przestrzeni badań teologicznych czy też szerzej rozumianej refleksji

${ }^{52} \mathrm{Na}$ temat samych portali wymiany między naukowcami Por. E. Rozkosz, Serwisy spolecznościowe dla naukowców (SSN) na przyktadzie Researchgate i Academia.edu, „Forum Bibliotek Medycznych", 7 (2014) nr 2, s. 16-24, http://forum.bg.umed.lodz.pl/.

${ }^{53}$ Por. S. Cisek, Nauka 2.0 nowe narzędzia komunikacji naukowej, https://www.researchgate. net/profile/Sabina_Cisek/publication/28808351_Nauka_20_nowe_narzedzia_komunikacji_naukowej/links/0c96052c54857aa8c6000000.pdf (dostęp: 14.03.2020).

${ }^{54}$ M. Hołowiecki, Analiza widoczności publikacji naukowych polskich humanistów w Internecie (Raport $n r$ 4), http://hdl.handle.net/10593/19751 (dostęp: 06.03.2020).

${ }_{55}$ E. Kulczycki, Blogi i serwisy naukowe. Komunikacja naukowa w kulturze konwergencji, http://hdl.handle.net/10593/2520. 
teologicznej, spełniającej reguły pracy naukowej, istnieje wiele tego typu stron, czy to prowadzonych przez jednego autora, czy to platform dla tego typu twórczości w obszarze teologii ${ }^{56}$.

\section{Źródla elektroniczne a warsztat pracy teologa}

W obliczu rozwiniętej i nadal dynamicznie rozwijającej się dziedziny źródeł elektronicznych naukowiec czerpiący nawyki z pracy ze źródłami drukowanymi musiał przemodelować szereg przyzwyczajeń i wypracowanych technik. Zwróciłem już uwagę na przesunięcie związane z poszukiwaniem odpowiednich materiałów: od przeglądania pojedynczych stron sugerujących interesującą zawartość (a znajdowanych zasadniczo przy pomocy standardowych wyszukiwarek) do korzystania ze złożonych multiwyszukiwarek, agregujących dane $\mathrm{z}$ wielu innych baz danych, które $\mathrm{z}$ kolei gromadzą dane $\mathrm{z}$ wielu czasopism $\mathrm{i}$ innych publikacji. Część tego typu instrumentów jest płatnych. Inne, bezpłatne, odsyłają często do baz pełnotekstowych, które już są płatne. Widać tu jasno, że uprzywilejowuje badacza związanie $\mathrm{z}$ instytucją, która subskrybuje dostęp do tych narzędzi i w ten sposób umożliwia go swoim pracownikom (lub szerzej: członkom społeczności).

Rozwiązany problem dostępu do omawianych narzędzi podprowadza od razu pod kolejny, jakim jest zapanowanie nad ilością informacji docierającą na biurko badacza. Już na marginesie tematu niniejszego opracowania warto dodać, że wielką pomoc w tym zakresie stanowią tzw. menedżery bibliografii. Programy te, ciągle rozbudowywane, pozwalają na sprawne gromadzenie zbiorów, właściwe ich opisywanie, porządkowanie zgromadzonych tekstów, potem pracę nad tekstami, organizowanie zdobytej wiedzy, przydzielanie zadań (sobie lub współpracownikom we współdzielonych projektach) i inne typy współpracy, a wreszcie redagowanie tekstów i opisów bibliograficznych. W praktyce niezwykle ważne okazuje się, by także dziedzinowe wyszukiwarki i bazy danych z zakresu teologii uwzględniały możliwość bezproblemowego eksportu danych do takich programów.

Ponadto teolog pracujący nieustannie $\mathrm{z}$ tekstami ma możliwość wzięcia pod uwagę rozwiniętej technicznej oferty w zakresie sprzętu ułatwiającego lekturę. Lektura tekstów z ekranu komputera jest uciążliwa, drukowanie na papierze jawi się jako niepotrzebny krok wstecz. Urządzenia takie jak tablet czy - jeszcze lepiej - wielkoformatowy czytnik e-booków (z technologią e-paper) znakomicie wspomagają pracę. Nie są one pozbawione słabości, ale ich doskonalenie bardzo szybko postępuje. Tymczasem można przez wykorzystanie usługi synchronizowania plików w chmurze powiązać ze sobą różne urządzenia i w ten sposób wykorzystać lepiej mocne strony każdego z nich.

${ }^{56}$ Trudno wymieniać tu pojedyncze przykłady. Warto zwrócić uwagę na serwisy agregujące dane z blogów teologicznych. Same platformy oferujące usługi blogowe prowadzą odpowiednie rankingi blogów według ich tematyki, kierując się jednak zautomatyzowanymi kryteriami pozamerytorycznymi. Idąc dalej w stronę moderowanego zbioru blogów, można znaleźć serwis www. theoradar.de (dostęp: 06.03.2020), który jest bazą danych zbierającą zawartość niemieckojęzycznych 472 blogów i 25 podcastów o tematyce religijnej, obejmujących ponad 56000 wpisów (stan: 13.03.2020) i prezentującą zebrane treści według kilku różnych kryteriów. 


\section{Zakończenie}

Prezentacja źródeł elektronicznych dokonana przez teologa zajmującego się wąskim zakresem badań nie może pretendować do kompletności w żadnym z przedstawionych tu zakresów. Na plan pierwszy wysunął się cel praktyczny, czyli własne zdanie sprawy $\mathrm{z}$ wykorzystania źródeł elektronicznych $\mathrm{w}$ procesie badawczym. Ten profil niniejszej wypowiedzi być może okaże się wartościowy dla specjalistów z dziedziny informacji naukowej, stawiających pytanie, w jaki sposób w praktyce przeciętny teolog-badacz de facto korzysta z nowych mediów.

Niewątpliwie na przestrzeni ostatnich lat bardzo rozwinęła się cała dziedzina źródeł internetowych istotnych dla teologa. Ważne, że wraz z niebywałym przyrostem liczby tekstów bieżących i archiwalnych zostały udoskonalone także technologie wspomagające przetwarzanie tej wielkiej ilości informacji oraz że rozwijają się narzędzia skierowane wprost do teologów. Zasadniczo usunięte lub pomniejszone zostały rozmaite niedoskonałości, o których jeszcze w $2005 \mathrm{r}$. pisał G. Strzelczyk ${ }^{57}$. Wobec problemu niestabilności ulokowania źródeł - silna ochrona instytucjonalna wielu inicjatyw naukowych pozwoliła na ustabilizowanie obecności treści naukowych w sieci; numery DOI pozwoliły na jednoznaczną identyfikację w przestrzeni wirtualnej poszczególnych tekstów oraz ich umiejscowienia. Wobec niejasności wokół praw autorskich - mocno postąpiły naprzód rozwiązania dotyczące licencji, ustalających prawa posługiwania się tekstem. Wobec rozproszenia rozrastających się zasobów informacji w Internecie - wspomniane bazy danych i złożone wyszukiwarki, mające coraz większy zasięg, świadczą o wychodzeniu naprzeciw temu wyzwaniu. Wobec problemów z techniką czytania - nowe technologie wskazują coraz lepsze rozwiązania.

Warto na koniec wyliczyć kilka postulatów. W odniesieniu do dostępności oficjalnych źródeł teologicznych obejmujących nauczanie Kościoła wciąż pozostają „białe plamy” w wersjach polskojęzycznych, które domagają się odpowiednich działań. Bodaj najboleśniejszą jest brak oficjalnego upublicznienia dokumentów Soboru Watykańskiego II. Poza tym szereg starszych zdigitalizowanych tekstów zamieszczanych na stronach watykańskich, włączywszy w to encykliki Jana Pawła II, wciąż nie doczekało się solidnej korekty po procesie automatycznego rozpoznania znaków.

W odniesieniu do pozyskiwania informacji o publikacjach użytkownik docenia przede wszystkim działalność Federacji Bibliotek Kościelnych FIDES, przejawiającą się w działających bazach online. W sferze postulatów warto podkreślić wartość ,jednego okienka" wyszukiwarki, które prowadzi nie tylko do opisu bibliograficznego, ale też do lokalizacji tekstu elektronicznego (gdy występuje). Dla polskiego teologa postulat ten dotyczy szczególnie bazy specjalistycznej EBNT. Wiele z indeksowanych tam tytułów jest dostępnych w Internecie w wolnym dostępie ${ }^{58}$. Prawdopodobnie obserwowane obecnie upowszechnianie

${ }^{57}$ Por. Strzelczyk, Teologia z sieci, s. 94.

${ }^{58}$ Moje wyrywkowe poszukiwania prowadzą do następującego wniosku: sporadyczne odniesienia EBNT do zasobów „Polony” skutkują często informacją o ochronie praw autorskich i niemoż- 
się identyfikatorów DOI wśród najlepszych periodyków teologicznych pomoże zaradzić problemowi uzupełnienia informacji o jednoznacznej lokalizacji tekstu elektronicznego. Zasada ,jednego okienka" stanowi także dla wielu pewien oczekiwany stan docelowy w odniesieniu do samej informacji bibliograficznej, a więc dotyczy unifikacji informacji pochodzącej z różnych źródeł. Z pewnością już od strony technicznej piętrzą się tu trudności: im większy zakres źródeł informacji, tym trudniej zbudować taki zunifikowany system i zapewnić kompletność danych. Problem ten dotyczy prawdopodobnie nie tylko działań na skalę światową, ale też tych, które organizują informację naukową w przestrzeni publikacji teologicznych w Polsce. W mojej ocenie naukowiec nigdy nie powinien rezygnować z poszukiwań wielopłaszczyznowych, a tym samym powinien zdobywać orientację w złożonym świecie cyfrowej informacji naukowej, bowiem perspektywa zunifikowanej wyszukiwarki rodzi nowe niebezpieczeństwa związane z zasadami priorytetyzacji informacji, jak i możliwości wykluczeń ważnych tekstów w związku z błędami lub niejednoznacznościami w ich klasyfikacji.

Ostatni postulat wiąże się z upowszechnieniem indywidualnych narzędzi do zarządzania informacją bibliograficzną, czyli menedżerów bibliografii. Rodzi się tu zapotrzebowanie na jednolite i precyzyjne opisy bibliograficzne oraz łatwość w ich imporcie na własny komputer. Warto pamiętać o tym, że zawartość baz elektronicznych kopiowana za pomocą tego typu narzędzi automatycznie przenika do zapisu bibliograficznego w publikacjach naukowych.

\section{REFERENCES / BIBLIOGRAFIA}

Bokwa Ignacy, Breviarium fidei. Wybór doktrynalnych wypowiedzi Kościoła, Poznań 2007.

Cisek Sabina, Nauka 2.0 nowe narzędzia komunikacji naukowej, https://www.researchgate.net/profile/Sabina_Cisek/publication/28808351_Nauka_20_nowe_narzedzia_ko-

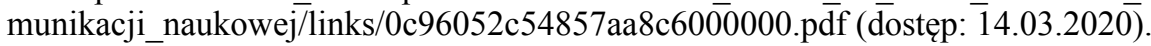

Congregation for the Doctrine of the Faith - Profile, http://www.vatican.va/roman_curia/congregations/cfaith/documents/rc_con_cfaith_pro_14071997_en.html (dostęp: 07.03.2020)

Denzinger Heinrich, Hünermann Peter, Enchiridion symbolorum definitionum et declarationum de rebus fidei et morum. Kompendium der Glaubensbekenntnisse und kirchlichen Lehrentscheidungen, Freiburg, Basel, Wien 1991.

Drabek Aneta, Pulikowski Arkadiusz, Możliwości wykorzystania bazy „ARIANTA” na przyktadzie bibliotekoznawstwa i informacji naukowej, w: Zarzadzanie informacja w nauce, red. D. Pietruch-Reizes, W. Babik, s. 145-154.

Engels Tim C.E., Istenič Starčič Andreja, Kulczycki Emanuel, Pölönen Janne, Sivertsen Gunnar, Are book publications disappearing from scholarly communication in the social sciences and humanities?, https://repozytorium.amu.edu.pl/bitstream/10593/24097/1/STI2018_paper_132.pdf (dostęp: 28.02.2020).

ności bezpośredniego udostępnienia tekstu, podczas gdy ten sam tekst jest dostępny w bazach Open Access lub na stronach samego czasopisma. 
Głowa Stanisław, Bieda Ignacy, Breviarium fidei. Wybór doktrynalnych wypowiedzi Kościoła, Poznań 1997.

Głowacka Ewa, Polskie repozytoria instytucjonalne jako miejsce dla otwartych zasobów naukowych i edukacyjnych, ,Zagadnienia Informacji Naukowej” 54 (2016) nr 1(107), s. 44-54.

Gwóźdź Łukasz, Strojek Jarosław, Hajda Andrzej, Nauczanie Kościoła katolickiego, Kraków 2003.

Hołowiecki Marek, Analiza widoczności publikacji naukowych polskich humanistów w Internecie (Raport $n r$ 4), http://hdl.handle.net/10593/19751 (dostęp: 06.03.2020).

Hoping Helmut, Systematische Theologie, w: Lexikon für Theologie und Kirche, t. 9, Freiburg, Basel, Wien 1993-2001, s. 1220-1221.

Hoping Helmut, Hünermann Peter, Kompendium der Glaubensbekenntnisse und kirchlichen Lehrentscheidungen. Enchiridion symbolorum definitionum et declarationum de rebus fidei et morum. Verbessert, erweitert, ins Deutsche übertragen und unter Mitarbeit von Helmut Hoping herausgegeben von Peter Hünermann, Freiburg 2017.

Kulczycki Emanuel, Blogi i serwisy naukowe. Komunikacja naukowa w kulturze konwergencji, http://hdl.handle.net/10593/2520.

Kulczycki Emanuel, Wzory publikacyjne polskich naukowców w latach 2013-2016. Nauki humanistyczne i społeczne, http://hdl.handle.net/10593/24460 (dostęp: 12.03.2020).

Mikołajuk Lidia, Repozytorium instytucjonalne jako nowa forma komunikacji naukowej, „Podkarpackie Studia Bibliologiczne:, 3 (2014), http://dspace.uni.lodz.pl/xmlui/bitstream/handle/11089/5071/repozytorium_instytucjonalne_1.pdf?sequence=1\&isAllowed $=\mathrm{y}$.

Morawiec Barbara M., Biblioteki cyfrowe. Tworzenie, zarządzanie, odbiór, Gliwice 2016.

Muc Agata, Elektroniczna Bibliografia Nauk Teologicznych jako źródło do badań historyczno-teologicznych, „Archiwa Biblioteki i Muzea Kościelne”, 109 (2018) s. 299314.

Olszowy Ewa, Czasopisma z zakresu nauk teologicznych $w$ bazie Directory of Open Access Journals (DOAJ), „Fides: Biuletyn Bibliotek Kościelnych”, 1-2 (2010), s. 108139.

Rahner Karl, Dogmen- und Theologiegeschichte - Gestern und Morgen, „Zeitschrift für Katholische Theologie“, 99 (1977) Nr 1, s. 1-24.

Rozkosz Ewa, Serwisy społecznościowe dla naukowców (SSN) na przykładzie Researchgate i Academia.edu, „Forum Bibliotek Medycznych”, 7 (2014) nr 2, 16-24, http:// forum.bg.umed.lodz.pl/.

Strzelczyk Grzegorz, Teologia z sieci. Kilka uwag o teologicznych zastosowaniach Internetu, w: Kościół w życiu publicznym. Teologia polska i europejska wobec nowych wyzwań. Materiaty VII Kongresu Teologów Polskich. Katolicki Uniwersytet Lubelski, 12-15 września 2004 r., t. 3: Dyskusje, komunikaty, uzupetnienia, dokumenty końcowe, red. K. Góźdź, K. Klauza, Lublin 2005, s. 89-101.

Szczepański Michał T., Cyfrowa kolekcja czasopism humanistycznych (Bazhum) http:// www.muzhp.pl/bazhum, „Przegląd Historyczny”, 101 (2010) nr 1, s. 101-106.

Witczak Jerzy, Teologiczne zbiory w polskich bibliotekach cyfrowych, „Fides: Biuletyn Bibliotek Kościelnych", 24-25 (2007) nr 1-2, s. 24-34.

Wójcik Edwin, Systematyczna teologia, w: Encyklopedia Katolicka, t. 18, red. E. Gigilewicz, Lublin 2013, kol.1380-1382. 


\title{
E-RESOURCES IN THE WORK OF A SYSTEMATIC THEOLOGIAN
}

\begin{abstract}
The practice of science has been revolutionised by the technical progress related to the popularisation of the electronic form of publication and the development of the global Internet network, which has shaped the new status of communication. The way research is conducted and its results disseminated in theology has changed as well. Systematic theology (here regarded as an area of studies in fundamental, dogmatic and moral theology) is a theological specialty which refers to multiple types of sources (the Bible, Church teaching, history of theology, the common Faith of the People of God, liturgy, etc.) as well as outcomes of research studies in other disciplines of science. Finally, it requires participation in the current theological discourse, hence the aforementioned changes facilitating access to source materials and current publications are of great significance for theologians, provided that they acquire the ability to take advantage of modern technologies. Due to the large number of sources available on the Internet and the small scale of the study, it is only feasible to name them by grouping various ways of their publication. While this does not come close to exhausting their entire range, it is possible to characterise them approximately and assess their credibility in a preliminary manner. The review conducted shows that particular publications inherit their credibility from the entities which publish them, hence priority is given to scientific institutions and recognised publishers as well as new entities established already in the Internet space, provided that they pursue a clear scientific policy. Given the ever-increasing amount of information, it is also important for a scientist to be familiar with the world of databases, especially topical ones, both bibliographic and full-text. Moreover, the study notes that a significant form of the theological thought development which has not yet been used to a great extent by the theological community is the scientific exchange on the Internet, either direct or mediated through specialised communication platforms.
\end{abstract}

Keywords: electronic resources; theology on the Internet; systematic theology; theological library; scientific communication; Open Access; Science 2.0 